\title{
GEOGRAPHIC VARIATION IN CLUTCH SIZE AMONG Lophura AND Syrmaticus PHEASANTS ON TAIWAN AND MAINLAND OF CHINA
}

\author{
Variação Geográfica do Tamanho do Ninho de Faisões (Lophura \\ e Syrmaticus) em Taiwan e na China Continental
}

Zuhao Huangl,2

Naifa Liu'

\begin{abstract}
Clutch size, the important parameters of bird reproduction, directly influences bird reproductive result. The difference of interspecific or/and intraspecific clutch size has been widely applied to explain life history evolution. In order to know the factors limiting clutch size of pheasants on island and examine Ashmole's hypothesis and Cody's hypothesis, clutch size and egg size of Lophura swinhoii and Syrmaticus mikado on Taiwan were compared with those of relative species on mainland of China. The average clutch size of L.swinhoii and S.mikado on Taiwan were significantly less than those of relative species on mainland. But the egg size of the two pheasants on Taiwan was notably bigger than those of relative species on mainland. They reduced clutch size and increased egg sizes, their reproductive strategies tended to k-selection. While the relative species on mainland laid more and smaller eggs, their reproductive strategies tended to rselection. The analysis on environmental factors showed the pheasants on Taiwan didn't support Ashmole's and Cody's hypotheses. Unexpected weather condition on island might lead to the breeding strategy on island tend to k-selection. Among Gallinaceous birds, there was a highly significant positive correlation between clutch size and their distributed area, and the number of subspecies. The breeding strategy of pheasants on island was determined by the effects of area and heredity.
\end{abstract}

Keywords: Lophura; Syrmaticus; Clutch size; Reproductive strategy; Geographic variation.

School of Life Sciences, Jinggangshan University, Ji'an Jiangxi Province, 343009, China.

School of Life Sciences, Lanzhou University, Lanzhou, Gansu Province, 730000, China.

Corresponding author: Naifa Liu, Address: School of Life Sciences, Lanzhou University, Lanzhou, Gansu Province, 730000 , China. Email: liu-nf@sina.com. 


\section{Resumo}

O tamanho do ninho é um importante parâmetro para reprodução de pássaros e influencia diretamente no seu resultado. A diferença de tamanho de ninhos, interespecíficos e/ou intra-específicos, tem sido muito utilizada para explicar a evolução da vida desses animais. A fim de estudar fatores limitantes no tamanho dos ninhos de faisão da ilha e examinar as hipóteses de Ashmole e de Cody, foram comparados tamanhos de ninhos e ovos de Lophura swinhoii e Syrmaticus mikado de Taiwan com os das mesmas espécies da China continental. A média de tamanho dos ninhos de L.swinhoii e S.mikado em Taiwan foi significativamente menor do que os das mesmas espécies do continente. Mas o tamanho dos ovos das duas espécies de faisão em Taiwan foi notavelmente maior do que os do continente. Eles reduziram o tamanho do ninho e aumentaram o tamanho dos ovos, com isso, suas estratégias reprodutivas tenderam à seleção-K. Enquanto as espécies do continente botaram mais e menores ovos, com isso, suas estratégias de reprodução tenderam à seleção-R. As análises dos fatores ambientais mostraram que os faisões em Taiwan não suportaram as hipóteses de Ashmole e Cody. Condições inesperadas de tempo podem ter levado à estratégia de reprodução, na ilha, a tender para seleção-K. Entre esses galináceos houve uma correlação positiva altamente significativa entre o tamanho do ninho, sua área de distribuição e o número de subespécies. A estratégia de reprodução dos faisões em Taiwan foi determinada pelos efeitos da área e da hereditariedade.

Palavras-chave: Lophura; Syrmaticus; Tamanho do ninho; Estratégia reprodutiva; Variação geográfica.

\section{Introduction}

Variation in clutch size in birds has stimulated a great deal of research, both descriptive and experimental (1). Most attention has focused on understanding variation in clutch size within populations, leaving the question of geographic variation in clutch size mostly to a series of studies that relate environmental variation to clutch size $(2,3,4,5)$. Of all the theories putting forth to explain the evolution of clutch size in birds, the foodlimitation hypothesis of Lack $(6,7,8)$ has gained the most acceptance. Several workers have extended Lack's ideas to include aspects of environmental stability, competition and predation (9, 10, 2, 11, 12) in an effort to explain many of the geographical trends in clutch size in bird. The observation that island species typically laid smaller clutches than mainland relative species did (13) still requires explanation. And the factors that limit the clutch size of pheasant on island were worth researching.

In certain environmental space, there was a definite carrying capacity (K). Due to densitydependent, carrying capacity might influence animal's reproduction. It's certain that the carrying capacity was low in small environmental space. So there might be area effect on clutch size in bird on island. However, an important and complementary method of studying clutch size evolution was through the use of genetics (14). Quantitative genetics was much used to research clutch size evolution. In this paper, we will discuss genetic effect on clutch size in bird.
Taiwan Island is a good region for research above problems. In the following pages, our general aim was to explain the evolution on clutch size and egg size of pheasants on island. Specially, we sought to: (1)evaluate Ashmole's and Cody's hypotheses through comparison of clutch size and egg size of Lophura and Syrmaticus pheasants between Taiwan and mainland of China; (2) assess putative area effect on clutch size; (3) estimate the relationship between clutch size and genetic diversity.

\section{Materials and Methods}

Taiwan locates between East China Sea and South China Sea, 21.9-25.2 ${ }^{\circ} \mathrm{N}, 120.1^{\circ}-122.0^{\circ}$ $\mathrm{E}$, about $120 \mathrm{~km}$ from mainland of China. The climate belongs to subtropic oceanic monsoon type. In the island there are Taiwan blue pheasant (Lophura swinhoii) and Taiwan Long-tailed pheasant (Syrmaticus mikado). Two relative species (L.nycthemera and L.leucomelana) of the Taiwan blue pheasant and three relative species (S.reevesii, S.ellioti and S.humiae) of the Taiwan Long-tailed pheasant are encountered on mainland of China. Besides the L.leucomelana, the breeding of these pheasants were separately researched and reported by ornithologists on Taiwan and mainland. Their materials were used and dealt with in this paper.

The egg size was determined by long diameter $(\mathrm{cm}) \mathrm{X}$ short diameter $(\mathrm{cm})^{2}$. The resident 
region of every species of pheasants on mainland was separately drawn on 1:40,000,000 the world map, using planimeter to calculate their distributed area. The area of the island was considered as the area that is occupied by pheasants on Taiwan.

\section{Results}

\section{Clutch size}

The average clutch size of L.swinhoii and S.mikado were separately $5.20 \pm 1.40$ and
$3.25 \pm 0.50$, which were significantly less than those of relative species on mainland, whereas there were no significant difference in clutch size among S.reevesii, S.ellioti and S.humiae within mainland (Table 1). The variation coefficient in clutch sizes of L.swinhoii was larger than that of L.nycthemera on mainland, whereas the variation coefficient in clutch size of S.mikado was similar to that of S.reevesii on mainland, but was smaller than that of S.humiae on mainland (Table1).

TABLE 1. Clutch size and its variation coefficiant (V.C.) of Lophura and Syrmoticus pheasants on Taiwan and mainland of China. ** significant difference, $p<0.01$; ${ }^{* *}$ most significant difference, $p<0.001$.

\begin{tabular}{|l|l|l|l|l|l|}
\hline \multicolumn{1}{|c|}{ Species } & $\mathbf{N}$ & \multicolumn{2}{|c|}{ Clutch size } & \multirow{2}{*}{ V.C. } & References \\
\cline { 3 - 4 } & & Mean \pm S.D. & Range & & \\
\hline Lophura swinhoii & 10 & $5.20 \pm 1.40$ & $3-7$ & 0.27 & $(17)$ \\
\hline $\begin{array}{l}\text { Lophura } \\
\text { nycthemere }\end{array}$ & 10 & $6.90 \pm 1.29^{* *}$ & $4-8$ & 0.19 & $(18)$ \\
\hline $\begin{array}{l}\text { Syrmaticus } \\
\text { mikado }\end{array}$ & 4 & $3.25 \pm 0.50$ & $3-4$ & 0.15 & $(19)$ \\
\hline $\begin{array}{l}\text { Syrmaticus } \\
\text { humiae }\end{array}$ & 7 & $7.57 \pm 1.51^{* * *}$ & $5-9$ & 0.20 & $(17)$ \\
\hline $\begin{array}{l}\text { Syrmaticus } \\
\text { reevesii }\end{array}$ & 25 & $7.68 \pm 1.18^{* * *}$ & $6-10$ & 0.15 & $(20)$ \\
\hline
\end{tabular}

\section{Egg size}

The egg size of L.swinhoii and S.mikado on Taiwan were significantly bigger than those of relative species on mainland (Table 2). Among the species on mainland, the egg size of L.nycthemera was bigger than that of L.leucomelana, and egg size of S.reevesii was the largest. There was significant difference in egg size between species within mainland. 
TABLE 2 Egg sizes of Lophura and Syrmaticus pheasant on Taiwan and mainland of China

\begin{tabular}{|l|l|l|l|l|}
\hline \multicolumn{1}{|c|}{ Species } & \multirow{2}{*}{$\mathbf{N}$} & \multicolumn{2}{c|}{ Egg size } & \multirow{2}{*}{ References } \\
\cline { 3 - 4 } & & Mean \pm S.D. & Range & \\
\hline Lophura swinhoii & 48 & 88.99 & & $(17)$ \\
\hline $\begin{array}{l}\text { Lophura } \\
\text { nycthemere }\end{array}$ & 30 & 73.07 & & $(18)$ \\
\hline Lophura & 10 & 61.61 & & $(21)$ \\
\hline Leucomelana & 0 & & & $(19)$ \\
\hline Syrmaticus mikado & 7 & $88.20 \pm 4.67$ & $79.45-93.30$ & $(22)$ \\
\hline Syrmaticus humiae & 33 & $54.70 \pm 3.83^{*}$ & $47.18-61.69$ & $(17)$ \\
\hline Syrmaticus ellioti & 10 & $52.31^{*}$ & & $(20)$ \\
\hline Syrmaticus reevesii & 90 & $59.44^{*}$ & & \\
\hline
\end{tabular}

* most significant difference, $\mathrm{p}<0.001$.

The relationship between clutch size and egg size, egg weight

The egg size and weight significantly decreased with increasing clutch size $(p<0.05$ and $\mathrm{p}<0.01$, Figure 1 and 2). Namely, egg size was generally conservative as opposed to clutch size $(7,8)$. Our evidence supported the hypothesis that reduced clutch size results in increased egg size.

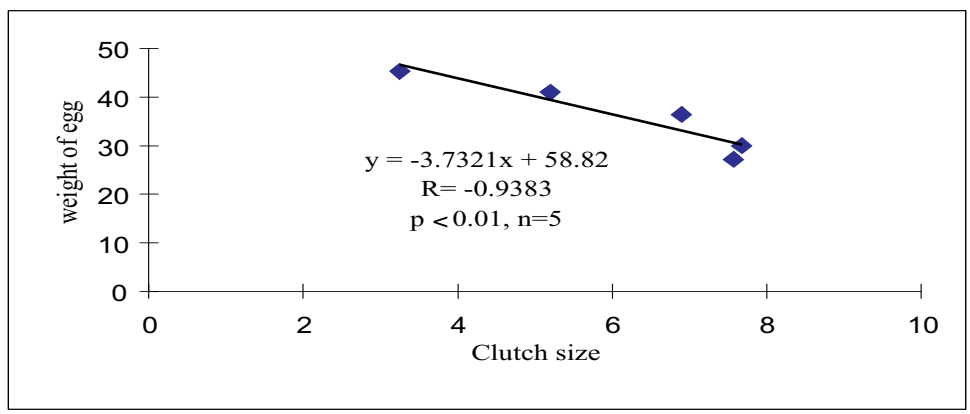

FIGURE 1. The relationship between egg size and clutch size of Lophura and Syrmoticus. Regression equation and correlation coefficient(r) are given. Each dot represents one species. 


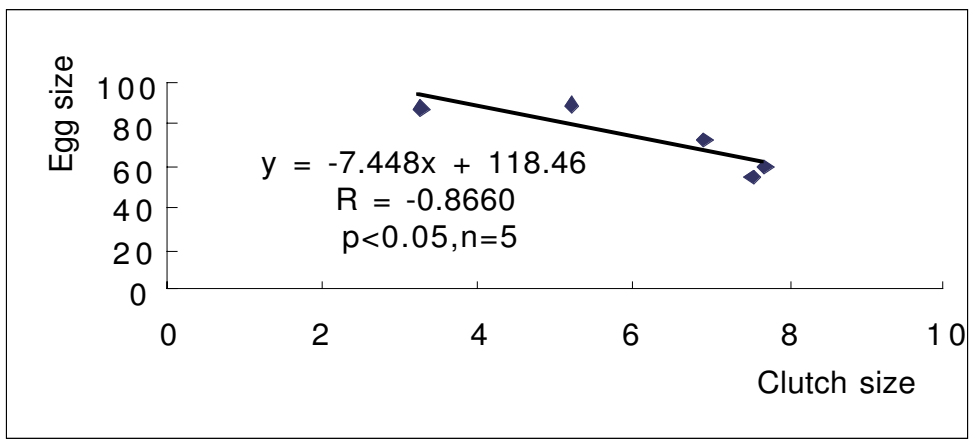

FIGURE 2. The relationship between weight of egg and clutch size of Lophura and Syrmoticus. Regression equation and correlation coefficient (r) are given. Each dot represents one species.

The average weights in eggs of the two species pheasants on Taiwan were weightier than those of their relative species on mainland, but the average weights of their clutch egg were lighter than those of species on mainland. This suggested that the cost in clutch eggs of the pheasants on Taiwan was less than that of those pheasants on mainland, because during breeding period the weight of females was similar each other (Table 3).

TABLE 3. Weights (g) of egg, clutch eggs and females during breeding period of Lophura swinhoii, Syrmaticus mikado on Taiwan and their relative species on mainland

\begin{tabular}{|l|l|l|l|l|l|l|}
\hline \multicolumn{1}{|c|}{ Species } & $\mathbf{N}$ & $\begin{array}{c}\text { Weight of } \\
\text { egg } \\
\text { (g) } \pm \text { S.D. }\end{array}$ & $\begin{array}{c}\text { Weight of } \\
\text { clutch eggs } \\
\text { (g) }\end{array}$ & $\mathbf{N}$ & $\begin{array}{c}\text { Weight of } \\
\text { females } \\
\text { (g) }\end{array}$ & References \\
\hline Lophura swinhoii & 48 & 41.0 & 213.20 & 2 & 948.0 & $(17)$ \\
\hline $\begin{array}{l}\text { Lophura } \\
\text { nycthenmere }\end{array}$ & 22 & $36.4 \pm 3.0$ & 251.16 & 2 & 953.5 & $(18)$ \\
\hline $\begin{array}{l}\text { Syrmaticus } \\
\text { mikado }\end{array}$ & 7 & $45.3 \pm 4.1$ & 147.18 & 8 & 925.0 & $(17)$ \\
\hline $\begin{array}{l}\text { Syrmaticus } \\
\text { humitiae }\end{array}$ & 33 & $27.2 \pm 2.88$ & 205.97 & 4 & 907.0 & $(22)$ \\
\hline $\begin{array}{l}\text { Syrmaticus } \\
\text { reevesii }\end{array}$ & 99 & 30.0 & 230.40 & 3 & 981.0 & $(20)$ \\
\hline
\end{tabular}


In short, Lophura swinhoii and Syrmaticus mikado on Taiwan reduced the number of eggs laid, enlarged egg size, and their reproductive strategies tended to k-selection, while, the relative species on mainland laid more and smaller eggs, their reproductive strategies tended to r-selection.

\section{Discussion}

\section{Ashmole's and Cody's hypotheses}

The phenomenon that the birds breeding on island lay smaller clutch size is common. Our data are consistent with the phenomenon. Crowell and Rothstein (13) attempted to use Ashmole's (9) climatic stable hypothesis and Cody's (10) energy allocate hypothesis to explain the smaller clutch size of birds breeding in Bermudan. They believed that, like tropical areas, islands areas were relatively stable and bird populations did not suffer great adult mortality at any season, thus, during the breeding season, bird population on island probably had less food for per individual than mainland population did.

The parameters of climatic stability are many, for example, frost-free period, annual variational ratio in temperature or precipitation, annual deviation of average temperature, frequency of typhoon and rainstorm, and so on. On the basis of the Chinese Natural Geographical Map, the frostfree period on Taiwan was lower than that of near mainland and annual variational ratio of precipitation was higher than that of near mainland and the annual deviation of temperature was lower than that of Guangxi, Fuzhou and Zhejiang, but higher than that of Guangdong (Table 4). It was difficult to estimate the climate of Taiwan was more stable than that of near mainland with these parameters. Besides, from June to October typhoon and rainstorm frequently occurred on Taiwan, and were stronger in June, July and August effecting on Taiwan during the breeding period of the two species pheasant. Ashmole's (9) hypothesis wasn't able to explain the smaller clutches and bigger eggs of pheasants breeding on Taiwan (Table 4).

\section{TABLE 4. Comparison of climatic stability on Taiwan and that near its mainland of China}

\begin{tabular}{|l|c|c|c|c|c|}
\hline \multicolumn{1}{|c|}{ Items } & $\begin{array}{c}\text { Taiwa } \\
\mathbf{n}\end{array}$ & $\begin{array}{c}\text { Guangdo } \\
\mathbf{n g}\end{array}$ & $\begin{array}{c}\text { Zhejian } \\
\mathbf{g}\end{array}$ & $\begin{array}{c}\text { Guangx } \\
\mathbf{i}\end{array}$ & Guizhou \\
\hline $\begin{array}{l}\text { Annual deviation of } \\
\text { temperature }\left({ }^{\circ} \mathrm{C}\right)\end{array}$ & $11-9$ & $9-8$ & $25-22$ & $19-13$ & $18-16$ \\
\hline Frost-free period (days) & $0-5$ & $0-10$ & $25-50$ & $0-10$ & $1-15$ \\
\hline $\begin{array}{l}\text { Annual variational rate } \\
\text { of precipitation (\%) }\end{array}$ & $10-25$ & $10-20$ & $10-20$ & $10-20$ & $10-15$ \\
\hline
\end{tabular}

According to Cody's (10) hypothesis, island populations were always close to environmental carrying capacity (K), the most adaptive reproductive strategy might lower the number of eggs laid and allocated the energy into other components of fitness such as foraging efficiency, predator avoidance or intra- and interspecific competition. The most common interspecific or/and intraspecific competitions are the competition for food, especially, when the food is the same or similar. The pheasants chiefly feed on plants, therefor the number of species and population density in an area may be considered as relative indexes of competitive intensity. There are three species pheasants on Taiwan, but there are five species in Zhejiang, six species in Guangdong, eight species in Guangxi and seven species in Guizhou (15). The population density of L.swinhoii on Taiwan was lower than that of L.nycthemere on mainland, but the population density of S.mikado was higher than those of S.reevesii and S.ellioti, whereas was lower than that of S.humiae (Table 5). Taiwan also didn't provide the evidence for Cody's hypothesis. 

Taiwan and their relative species on mainland

\begin{tabular}{|l|c|c|c|}
\hline \multicolumn{1}{|c|}{ Species } & \multicolumn{2}{|c|}{ Population density (ind./km ${ }^{2}$ ) } & \multirow{2}{*}{ References } \\
\cline { 2 - 3 } & $\begin{array}{c}\text { Breeding } \\
\text { season }\end{array}$ & $\begin{array}{c}\text { Unbreeding } \\
\text { season }\end{array}$ & \\
\hline $\begin{array}{l}\text { Lophura swinhoii } \\
\begin{array}{l}\text { Lophura } \\
\text { nycthemere }\end{array}\end{array}$ & $13.0-18.0$ & $(17)$ \\
$\begin{array}{l}\text { Syrmaticus } \\
\text { mikado }\end{array}$ & $41.2-44.2$ & $(17)$ \\
$\begin{array}{l}\text { Syrmaticus } \\
\text { humiae }\end{array}$ & 22.4 & $18.0-32.0$ & $(17)$ \\
$\begin{array}{l}\text { Syrmaticus ellioti } \\
\text { Syrmaticus } \\
\text { reevesii }\end{array}$ & 3.5 & 33.0 & (17) \\
\hline
\end{tabular}

Island is as small as patch on mainland, owing to the edge effect, the influence of natural calamities upon island is stronger than upon mainland. Typhoon and rainstorm frequently occur from May to October on Taiwan, mostly in July and August, often causing severe disaster. These climatic calamities are hard to forecast and mostly happen during brood period of the two species pheasants. The extreme weather on Taiwan may explain the smaller clutch size and larger eggs of the pheasants breeding in the island. The larger eggs can hatch larger and stronger young with a higher survival rate, which is advantageous for the population inhabiting such area.

\section{Area effect}

Every environmental space has a definite carrying capacity. However, clutch size is significant negative correlated with population density during breeding season $(\mathrm{r}=-0.9973, \mathrm{p}<0.01, \mathrm{n}=3)$, which is consistent with Ricklefs's prediction (2). Due to the density-dependent, carrying capacity may influence animal's reproduction. So there may be area effect on clutch size in bird. The clutch size of Gallinaceous birds is dependent on their distributed areas, this relationship is highly significant (Figure 3, $\mathrm{r}=0.7697, \mathrm{p}<0.001, \mathrm{n}=22$ ). In the smaller environmental space, there is often lower carrying capacity; on the contrary, there is higher one. So the breeding strategy of species that have bigger distributed area tends to r-selection, the contrary is inclined to k-selection. 


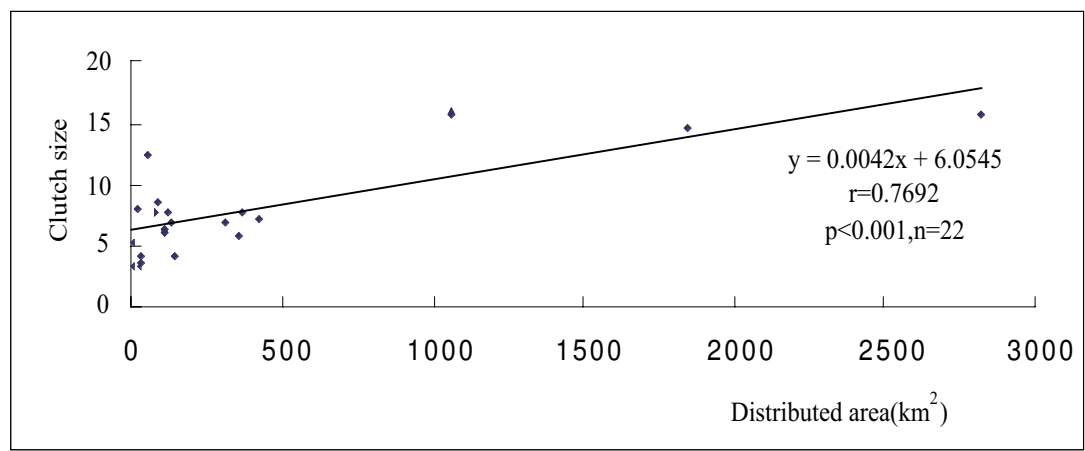

FIGURE 3. The relationship between clutch size and distributed area in Galliforms. Regression equation and correlation coefficient (r) are given. Each dot represents one species.

The area of Taiwan is small, only $3.6 \times 10^{4} \mathrm{~km}^{2}$, and the populations of pheasants on Taiwan are always near to the environmental carrying capacity, thus the breeding strategy of pheasant tends to k-selection.

\section{Genetic diversity effect}

Genetic variation is usually detectable for clutch size in birds (16). Among Gallinaceous birds, there is a significant positive correlation between clutch size and the number of subspecies ( $\mathrm{r}=0.5776$, $\mathrm{p}<0.05, \mathrm{n}=22$, Figure 4). As is well known, the more the number of subspecies is, the higher genetic diversity of the species is, because the species has more genotype. In the face of environmental variability, either spatial or temporal, an animal has more selection and more pheotypic plasticity when the species has more genotype. The average response will be a genetically determined compromise and subject to temporal and spatial variation in natural selection. L.swinhoii and S.mikado are endemic species on Taiwan and have no subspecific divergence, so their clutch sizes are small. Moreover, the number of subspecies among Gallinaceous increases with their distributed area increasing ( $\mathrm{r}=0.8890, \mathrm{P}<0.001, \mathrm{n}=22$ ) (table 6). So area effect associated with genetic effect influences clutch size in birds.

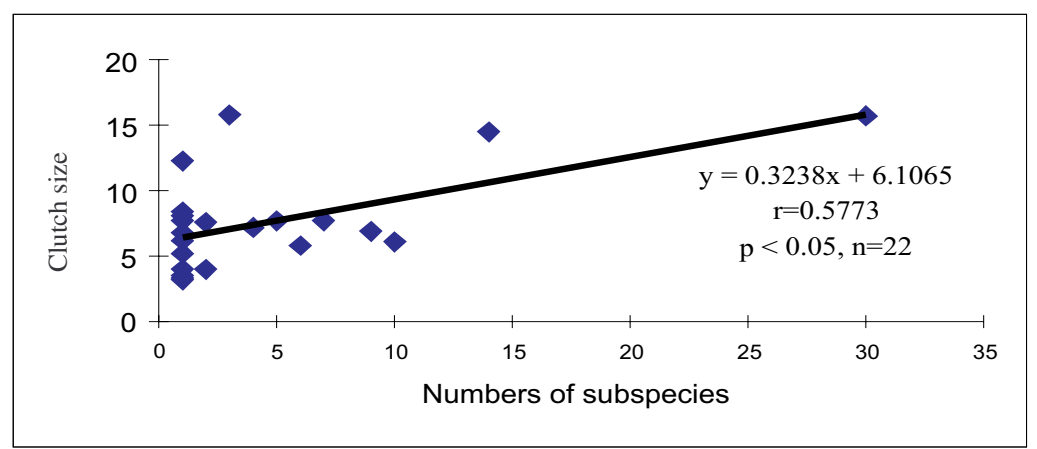

FIGURE 4. The relationship between clutch size and numbers of subspecies in Galliforms. Regression equation and correlation coefficient(r) are given. Each dot represents one species. 
TABLE 6. Distributed areas, clutch sizes and numbers of subspecies of 22 Galliforms species

\begin{tabular}{|c|c|c|c|c|c|c|}
\hline Species & $\begin{array}{c}\text { Distributed } \\
\text { area } \\
\left(\mathbf{x} 10^{4} \mathbf{m}^{2}\right)\end{array}$ & $\begin{array}{c}\text { Clutch } \\
\text { size }\end{array}$ & V.C. & $\begin{array}{c}\text { Numbers } \\
\text { of } \\
\text { subspecies }\end{array}$ & $\begin{array}{c}\text { Nest } \\
\text { number }\end{array}$ & Reference \\
\hline $\begin{array}{l}\text { Tetraogallus } \\
\text { tibetanus }\end{array}$ & 353.04 & $5.8 \pm 1.28$ & 0.22 & 6 & 8 & $\begin{array}{l}\text { (23) and this } \\
\text { paper }\end{array}$ \\
\hline $\begin{array}{l}\text { Tetraogallus } \\
\text { himalayensis }\end{array}$ & 421.48 & $7.2 \pm 2.40$ & 0.33 & 4 & 17 & $\begin{array}{l}(24) \text { and this } \\
\text { paper }\end{array}$ \\
\hline $\begin{array}{l}\text { Tetraophasis } \\
\text { obscurus }\end{array}$ & 33.00 & $3.5 \pm 0.58$ & 0.17 & 1 & 4 & $(25)$ \\
\hline $\begin{array}{l}\text { Tetraophasis } \\
\text { szechenvii }\end{array}$ & 25.90 & $3.3 \pm 0.58$ & 0.18 & 1 & 3 & (26) \\
\hline $\begin{array}{l}\text { Alectoris } \\
\text { chukar }\end{array}$ & 1845.2 & $14.5 \pm 3.66$ & 0.25 & 14 & 8 & (27) \\
\hline $\begin{array}{l}\text { Alectoris } \\
\text { magna }\end{array}$ & 52.8 & $12.3 \pm 3.12$ & 0.25 & 1 & 7 & (28) \\
\hline $\begin{array}{l}\text { Perdix } \\
\text { dauuricae }\end{array}$ & 1062.4 & $15.8 \pm 2.76$ & 0.17 & 3 & 34 & (29) \\
\hline $\begin{array}{l}\text { Ithaginis } \\
\text { cruentus }\end{array}$ & 110.25 & $6.1 \pm 1.28$ & 0.21 & 10 & 24 & (30) \\
\hline $\begin{array}{l}\text { Tragopan } \\
\text { temminckii }\end{array}$ & 141.75 & $4.0 \pm 0.82$ & 0.20 & 1 & 7 & (31) \\
\hline $\begin{array}{l}\text { Tragopan } \\
\text { caboti }\end{array}$ & 32.40 & $4.0 \pm 1.41$ & 0.35 & 2 & 4 & (32) \\
\hline $\begin{array}{l}\text { Crossoptilon } \\
\text { crossoptilon }\end{array}$ & 81.00 & $7.7 \pm 2.30$ & 0.30 & 5 & 6 & (33) \\
\hline $\begin{array}{l}\text { Crossoptilon } \\
\text { auritum }\end{array}$ & 90.00 & $8.4 \pm 2.50$ & 0.30 & 1 & 8 & (34) \\
\hline $\begin{array}{l}\text { Crossoptilon } \\
\text { mantchuricum }\end{array}$ & 20.00 & $8.1 \pm 2.48$ & 0.31 & 1 & 55 & (22) \\
\hline $\begin{array}{l}\text { Lophura } \\
\text { nycthemere }\end{array}$ & 312.8 & $6.9 \pm 1.29$ & 0.19 & 9 & 10 & (18) \\
\hline $\begin{array}{l}\text { Lophura } \\
\text { swinhoii }\end{array}$ & 3.60 & $5.2 \pm 1.40$ & 0.27 & 1 & 10 & (17) \\
\hline $\begin{array}{l}\text { Pucrasia } \\
\text { macrolopha }\end{array}$ & 371.00 & $7.7 \pm 1.16$ & 0.15 & 7 & 17 & $(35,36)$ \\
\hline $\begin{array}{l}\text { Syrmaticus } \\
\text { reenesii }\end{array}$ & 81.00 & $7.7 \pm 1.18$ & 0.15 & 1 & 25 & (20) \\
\hline $\begin{array}{l}\text { Syrmaticus } \\
\text { humiae }\end{array}$ & 122.00 & $7.6 \pm 1.51$ & 0.20 & 2 & 7 & (37) \\
\hline $\begin{array}{l}\text { Syrmaticus } \\
\text { mikado }\end{array}$ & 3.60 & $3.2 \pm 0.50$ & 0.15 & 1 & 4 & (17) \\
\hline $\begin{array}{l}\text { Chrysolo phus } \\
\text { amherstiae }\end{array}$ & 108.00 & $6.2 \pm 0.45$ & 0.07 & 1 & 5 & (38) \\
\hline $\begin{array}{l}\text { Chrysolophus } \\
\text { pictus }\end{array}$ & 135.00 & $6.8 \pm 1.14$ & 0.17 & 1 & 8 & $(39,40)$ \\
\hline $\begin{array}{l}\text { Phasianus } \\
\text { colchicus }\end{array}$ & 2817.00 & $15.7 \pm 3.75$ & 0.24 & 30 & 20 & (41)Liu, 1998 \\
\hline
\end{tabular}




\section{Acknowledgements}

This work was supported by National Natural Science Foundation of China (No.30530130).

\section{References}

1. VanderWerf E. Lack's clutch size hypothesis: an explanation of evidence using meta-analysis. Ecology 1992; 73:1699-1705.

2. Ricklefs RE. Geographical variation in clutch size among passerine birds: ashmole's hypothesis. Auk 1980; 97:38-49.

3. Koenig WD. Geographic variation in clutch size in the Northern Flicker Colaptes auratus: support for Ashmole's hypothsis. Auk 1984; 101:698-706.

4. KoenigWD. Geographical ecology of clutch size variation in North American woodperkers. Conder 1986; 88:499-504.

5. Young BE. Geographical and seasonal patterns of clutch size variation in House wrens. Auk 1994; 111:545-555.

6. Lack D. The significance of clutch size in birds, parts I and II. Ibis 1947; 89:302-352.

7. Lack D. The natural regulation of animal numbers. Oxford (England): Clarendon; 1954.

8. Lack D. Ecological adaptations for breeding in birds. London (England): Methuen; 1968.

9. Ashmole NP. The regulation of numbers of tropical oceanic birds. Ibis 1963; 103: 145-173.

10. Cody ML. A general theory of clutch size. Evolution 1966; 20:174-184.

11. Slagsvold T. Clutch size variation of birds in relation to nest predation on the cost of reproduction. Journal of Animal Ecology 1984; 53:945-953.

12. Lima SL. Clutch size in birds: a predation perspective. Ecology 1987; 68:1032-1070.

13. Crowell KL, Rothstein SI. Clutch sizes and breeding strategies among Bermudan and North American passerines. Ibis 1981; 123:42-50.
14. Godfray DCJ, Partridge L,Harvey PH. Clutch size. Annu Rev Ecol Syst 1991; 22:409-429.

15. Li XT. Game birds of China-Their distribution and status. Beijing (China): International Academic Publisers; 1996.

16. Boag PT, Noordwijk AJ. Quantitative genetic. In Avian Genetics: A Population and Ecological Approach Academic. London (England): Academic Press; 1987.

17. Lu TC, Zhang WF. Editors. Rare and Endangered Galliformes of China, Their Natural History and Conservation. Taiwan(China): Chung Thai Science and Technology; 1993.

18. Gao YR, Zhang YC. The ecology of the silver pheasant in Dinghushan Biosphere Reserve. In: Hill DH, Garson PJ, Jenkins D. editors. Pheasants in Asia, WPA, Reading (England); 1989.

19. Yao ZD, Nai TL, Cai MY, Hang XZ, Xu FX. Breeding ecology of Mikado pheasant in the Zueyenshi Nature Reserve. Proceedings of the Third Symposium of strait both sides on birds. Taiwan (China); 1998.

20. Wu ZK, Li ZM, Wang JH. Progress in research on Reeve's pheasant in China. Ann. Rev. WPA 1995; 39-43.

21. Baker EDS. Fauna of British India, including Coylon and Burma. Yarlor and Francis; London (England): 1928.

22. Liu HJ, Liu BS. The Brown Eared-pheasant. Beijing (China): China Forestry Publishing House; 1991.

23. Zheng SW, Pi NL. Ecological investigation of the Tibetan Snowcock, Tetraogallus tibetanus. Chinese Journal of Zoology 1979; 24-29.

24. Liu NF. Breeding behaviour of Koslov's snowcock (Tetraogallus himalayensis koslowi) in northwestern Gansu, China. Game and Wildlife Science 1994; 11:167-177.

25. Wu Y, Pong JT. Study on breeding ecology of the pheasant Grouse. Acta Ecologica Sininca 1994; 14(2):221-222.

26. Liu SC, Ren C. The pheasant grouse in Tibet. Chinese Wildlife. 1992; 5-8. 
27. Wang JP, Guo RJ. Ecological study on the breeding habits of chukar partridge in Luyashan Natural Reserve. Zoological Studies in China. Beijing (China): Chinese Forestry Publishing House; 1998.

28. Liu NF. Ecology of przewalski's rock partridge (Alectoris magna). Gibier Faune Suavage 1992; 9:605-615.

29. Zhang ZW, Wu YC. The Daurian partridge (Perdix dauuricae) in north-central China. Gibier Faune Sauvage 1992; 9:597-604.

30. Liu NF. Breeding of Beicki's blood pheasant (Ithaginis cruentus beicki) in northwestern Gansu, China. Game and Wildlife Science 2000; 17(1):17-27.

31. Li XT. On the breeding habits of Redbellied tragopan. Acta Zoologcial Sinica 1987; 33(1):99100.

32. Zheng GM, Zhao XR, Song J, Liu ZX. On the breeding ecology of the Cabot's tragopan Tragopan caboti. Acta Ecologica Sinica 1986; 5:379-385.

33. Ge MJ, Dong DF, Long WX. Breeding ecology of Crossoptilon crossoptilon. Chinese Wildlife 1995; (6):8-12.

34. Li GY,.Zhang RY. A preliminary report on the Blue Eared-pheasant, Crossoptilon auritum, in Wanglang Nature Reserve. Sichuan Journal of Zoology 1985; 4(1):7-9.
35. Han DM, Wang QS. Ecology of Joretian koklass pheasant. Zoological Research 1993; 14(1):27-34.

36. Zhou TL, Wang PX, Han FR. A preliminary study on the ecology of Koklass pheasant (Pucrasia maerolopha) in Guanshan forest. Zoological Research 1996; 17(1):52-58.

37. Liu XH, Zhou F, Pan G.. Breeding habits of Symaticus humiae burmannicus. Acta Zoologica Sinica 1991; 37(3):332-333.

38. Han LX, Yang L, Zheng BL. Observation on breeding ecology of Lady Amherst's pheasant. Zoological Research 1989; 10(4):285-294.

39. Yu ZG, Liang H, Liang W. Breeding ecology of Golden pheasant. Chinese Journal of Zoology 1997; (1):41-44.

40. Yang JL, Wu ZK, Liu QW. Preliminary remarks on the breeding behavious and feeding habits of the Chinese Copper Pheasant. Zoological Research 1982; 2(3):243-246.

41. Piao RZ, Wang WM, Chen GJ. Breeding habits of Ring-necked pheasant. Chinese wildlife 1984; (2): $1-5$.

42. Liu NF, Zhou TL. Breeding behaviour of Koslov's snowcock (Tetraogallus himalayensis koslowi) in northwestern Gansu, China. Game and Wildlife Science 1998; 15(10):21-29.

Recebido em / Received: January 14, 2006 Aceito em / Accepted: March 23, 2006. 